Nationally Accredited No. 30/E/KPT/2018 Dated 24th October 2018

This work is licensed under a Creative Commons Attribution-NonCommercial 4.0 International License

\title{
Gender Violence, Gender Justice and Gender-Based Laws: An Analysis of Pattern and Policies in India and Indonesia
}

\author{
Dr. Neelam Tyagi
}

\author{
Campus Law Centre, Faculty of Law, \\ University Of Delhi, New Delhi, India \\ Email: n.neelamtyagi@gmail.com; ntyagi@law.du.ac.in
}

Submitted : 2020-08-31 | Accepted : 2020-09-27

\begin{abstract}
If we look at the status of women in a particular society, we can get a fair idea about its social organization and standard. Violence against women is a challenge against the right to equality and an extreme form of violation of human rights. From ancient times to the modern era, women face discrimination, exploitation, and violence in every walk of their life, and this phenomenon is prevalent across all borders. Every civilized society tries to protect its members both in public and private spaces with the help of a set of laws and rights. Hosts of laws and beneficial legislation enacted to ameliorate women's condition have failed to achieve the desired purpose due several factors. Thus mere enactment of laws will not serve the desired purpose until they are effectively implemented and assertively claimed by women. This paper presents a comparative analysis of the various forms of gender violence and the status of the gender-based laws that are enacted for achieving gender justice in India and Indonesia. It analyses the extent to which these women favoring laws of both countries prevent the frequency of the occurrence of gender violence and some recommendations for bringing about changes to this situation.
\end{abstract}

Keywords: $\quad$ gender justice; gender violence; gender-based laws; poor implementation of laws and policies; right to equality and non-discrimination in india and indonesia.

\section{INTRODUCTION}

Violence against women ${ }^{1}$ is an omnipresent phenomenon and both India and Indonesia are no exceptions. Violence against women is discriminatory, hampers a women's capacity to enjoy their legal

rights, fundamental freedoms, and violative of their numerous human rights. Among the wide arrays of violence directed against women some are extensively discussed, whereas others do not receive enough

1 Violence against women is "any act of genderbased violence that results in, or is likely to result in, physical, sexual or psychological harm or suffering to women, including threats of such acts,

coercion or arbitrary deprivation of liberty, whether occurring in public or private life." Source: The Declaration on the Elimination of Violence against Women 1993. 
attention (like female genital mutilation, poor political participation of women, sex tourism etc.). ${ }^{2}$ If we look at the women in Indonesia, they are not regarded as weak but possessing extraordinary power. ${ }^{3}$ The efforts towards women's emancipation began in the 19th century when the demand for rights and education increased in Indonesia. ${ }^{4}$ From 1955 onwards progress is evident in terms of women's empowerment in education, gender equality, and other segments. ${ }^{5}$

Women in Indonesia undertake economic activities, run businesses, and play essential roles both inside and outside the family. Some traditional matriarchal and matrilineal society grants inheritance of property and family names from mothers to their daughters. ${ }^{6}$ But issues like child marriage, domestic violence, trafficking, sexual abuse persists. A survey, commissioned by the Women's Empowerment and Child Protection Ministry and conducted by the Central Statistics Agency (BPS), concluded that one in three women in Indonesia suffered violence in

2 Meiwita Budiharsana, Female circumcision in Indonesia: extent, implications and possible interventions to uphold women's health rights, Population Council, Jakarta (2004) < https://knowledgecommons.popcouncil.org/cgi/vi ewcontent.cgi? article $=1033 \&$ context=department s_sbsr-rh> Accessed: 27-07-2019.

3 Luh Ketut Suryani, 'Balinese Women in a Changing Society' (2004) 32, The Journal of the American Academy of Psychoanalysis and Dynamic Psychiatry 217.

4 Robinson, Kathryn May and Bessell Sharon, 'Women in Indonesia: Gender, Equity and Development', (2002) 8 Dari Indonesia assessment series, Institute of Southeast Asian Studies, 5.

5 Global Network for Advanced Management, what are the Obstacles to Women in the Global Workforce?

<https://globalnetwork.io/perspectives/2017/03/w hat-are-obstacles-women-global-workforce> Accessed: 28-06-2020.

6 Sankari Rathina, 'World's largest matrilineal society', (2016) (22 September) < http://www.bbc.com/travel/story/20 their lifetime. ${ }^{7}$ Above all, the abusive practice of "virginity testing" 8 and genital mutilation having no medical benefits continues. $^{9}$

Similarly, the traditional Indian religious communities, especially the Hindu ancient texts like Upanishads, Sastras, and Puranas respect and treat women as God. ${ }^{10}$ However, in modern times women are subjected to abuse and denial of their fundamental rights. The ancient Indian communities treated both the sexes with parity and followed liberal practices in every sphere of their life. ${ }^{11}$ All this gradually changed and numerous forms of atrocities directed against women originated from foreign invasions. From the 19th century, the feminist movements stood against these wrongs and focused on women's crucial areas. They stressed educating Indian women, demanded property rights for widows, and prevented discrimination and inequality in its every form. ${ }^{12}$ Today, some forty-one women favoring laws are passed in India that safeguards women from diverse

160916-worlds-largest-matrilineal-society> Accessed: 23-06-2020.

7 Margareth S. Aritonang 'Survey finds widespread violence against women', The Jakarta Post Jakarta, (2017) (March 31) <https://www.thejakartapost.com/news/2017/03/3 1/survey-finds-widespread-violence-againstwomen.html > Accessed: 29-10-2020.

8 Human Rights Watch, Indonesia Events of 2018 $<$ https://www.hrw.org/worldreport/2019/country-chapters/indonesia> Accessed: 30-06-2020.

9 Article 1 of the Ministry of Health Regulation No.6/2014.

10 McDaniel, Offering Flowers, Feeding Skulls: Popular Goddess Worship in West Bengal, (Oxford University Press, 2004) 90.

11 Julia Leslie, The Perfect Wife: The Orthodox Hindu Women (Oxford University Press, 1989) 320.

12 However, the Women Reservation Bill 2010, that reserves $33 \%$ seats for women in the Parliament as well as State assemblies is yet to become an Act in India. 
forms of violence. These provisions have a limited impact on the patriarchal traditions and practices that continue to rule Indian society. India is still a county dominated by males, and women are regarded as subordinate or inferior. Women are subjected to various forms of abuse and brutalities in rural and urban settings. If we look at the statistics, the frequency of crimes against women is continuously rising in public and private spaces. ${ }^{13}$ Rape, torture, assault, sexual harassment, eve-teasing, stalking is recurrent. Every one woman out of three is beaten, coerced into sex, or has suffered domestic violence at least once in her lifetime. ${ }^{14}$

According to a current study conducted by a Singapore-based research company Value Champion, both India and Indonesia ranked to be the least safe for women out of fourteen countries. Indonesia is ranked as the second-most dangerous place for women in the Asia Pacific region (ranked 13th), with India scoring the lowest in the list (ranked 14th). The study cited poor access to health care, lax laws regarding women's safety, and overall gender inequality as the reasons behind Indonesia and India featuring at the bottom of the list. ${ }^{15}$ Apart from this study, various other research studies and reports show the presence of deeply patriarchal attitudes entrenched in these two countries leading to women fearing their well-being. Both countries share many similarities in

13 National Crime Record Bureau, Crime in India of Ministry of Home Affairs, the National Crime Record Bureau statistics prove that women face a vast number of issues concerning crime against them.

14 Violence against women, In: Women in South East Asia: A health profile, (New Delhi, WHO regional office for South East Asia, 2000) 147-60.

15 Devina Heriyanto, 'Indonesia ranked second-most dangerous place for women in Asia Pacific: Study' The Jakarta Post, Jakarta (March 6, 2019) < https://www.thejakartapost.com/news/2019/03/ terms of being populated by people from varied cultural backgrounds, multiple languages, ethnicities, cultural customs, and religions. ${ }^{16}$ In the context of women, they face marginalization in both these countries. They are generally socialized to be submissive and relegated to secondary roles and subordinate status due to their respective patriarchal cultures. This makes them susceptible to inadequate bargaining power in their relationships and vulnerable to different types of discrimination. They have fewer rights and are married off even before they attain sufficient maturity. Both countries have framed numerous laws that promote women's interest. However they still face issues about their safety, health care, and opportunities leading to their low ranking on different parameters related to gender justice.

With this backdrop of the prevalence of contentious issues related to women in both the countries, a need was felt to study the effect and impact of granting various constitutional, legal, and human rights to women in both these countries. There is perhaps the first paper that presents a detailed comparative analysis of all the gender-based violence directed against women and the status of gender justice achieved so far in India and Indonesia. This research paper's inspiration is to draw a parallel between both countries that share a historical connection. It is necessary to assess the law, policies, and

06/indonesia-ranked-second-most-dangerousplace-for-women-in-asia-pacific-study.html> Accessed: 29-10-2020.

16 Pallavi Aiyar, 'Spot the similarities: unity in diversity in India and Indonesia', August 29, 2017, < https://www.thehindu.com/opinion/op-ed/spotthe-similarities/article19576750.ece> Accessed: 29-10-2020.

See 2010 Sensus penduduk (Statistics on the population of Indonesia) and the 2011 Census of India. 
practices followed within these two jurisdictions to undertake affirmative steps towards alleviating women's conditions in both these countries.

\section{LEGAL MATERIALS METHODS}

This paper embarks on comparative analysis and evaluation of the role, status, and position of women in these two countries, both in public and private spaces. The paper generalizes the interconnection between gender violence, gender injustice, and the role of law in promoting gender equality. The method and material used for this research is an amalgamation of various sources and data. Following the doctrinal research method, it revisits the existing legal material, judicial pronouncements, statistical data of national government agencies, and internationally recognized organizations. With assistance from these sources, the paper explains how women still face discrimination and inequality in almost all quarters. The material derived from the mentioned sources will be qualitatively and quantitatively evaluated to know about the current violence and inequality against women and the extent to which women lag in their economic, social, and political achievements. It emphasizes how the enacted laws, various legal and policy measures undertaken for raising the women's status in these two countries, are inadequate in tackling gender violence. With a comparative analysis of the degree of the pervasiveness of gender violence in both India and Indonesia, the paper summarizes and suggests the contentious areas that require further governmental and policy deliberations and interventions. The paper proposes that though in contemporary times women are provided several rights, remedies and opportunities to voice their opinion against the deep-rooted traditions, social restrictions and gender violence through gender-based laws but much remains to be done to attain inclusive gender justice.

\section{RESULT AND DISCUSSION Gender Justice Concerns under Indian and Indonesian Constitution}

India is one of the world's largest democracies that is inhabited by various religious communities. These communities live in peace and harmony, and enjoy equality in every walks of their life. The Indian Constitution aims at providing liberty, equality, and dignity to every citizen, especially to women who have faced various forms of violence in the past. The Indian constitution under Article 14 grants equality before the law and Article 15 prohibits all forms of discrimination based on religion, race, caste, sex, or place of birth. Article15(3) permits the state to make special provisions in favor of women and children. Article 16 grants equality of opportunity for all citizens in employment or appointment to any office. Apart from these fundamental rights provided under Part III of the constitution, Article 51(A) (e) makes it a duty of every citizen to renounce practices derogatory to women's dignity. Further, Article 243 D (3) makes provision for the reservation of seats for women in every Panchayat. Article 243 D (4) makes similar reservation of offices of Chairpersons in Panchayats, Article $243 \mathrm{~T}$ (3) for reservation of seats in a Municipality and Article $243 \mathrm{~T}$ (4) for reservation of offices of Chairpersons in Municipalities for providing justice and equality for women.

Like India, the 1945 Constitution of the Republic of Indonesia is the highest law of the land and the basis for all law in Indonesia. The Indonesian Constitution, under its various Articles, provides equality to its citizens. Chapter X on Citizens and Residents 
in its Article 27 grants equality before the law and the right to work and to earn a humane livelihood. Chapter XA on Human Rights under its Article 28D states that every person will have the rights of recognition, guarantees, protection, and equal treatment before the law apart from the right to work, receive fair and proper remuneration and treatment in employment and the right to obtain equal opportunities in government. Article $28 \mathrm{H}$ (2) states that every person shall have the same opportunity and benefits to achieve equality and fairness. Under Chapter XIII on Education, Article 31 (4) guarantees that the state shall prioritize the budget for education to fulfill the needs of implementation of national education. For Indonesian women, some eleven laws regarding women's rights are enacted out of which six have practical benefits. ${ }^{17}$ However, despite the constitutional protection by this supreme law, around 282 local bylaws exist that are discriminatory towards Indonesian women and their rights. ${ }^{18}$ Even the CEDAW report of 2013 highlighted Indonesia's failure to abide by international human rights laws

17 The Law of the Republic of Indonesia Number 8 Year 2012 on Election of Members of the House of Representatives, Regional Representatives Council and the Regional Representatives Council called PEMILU, Law of the Republic of Indonesia Number 23 Year 2004 on the Elimination of Domestic Violence, Law of the Republic of Indonesia Number 12 Year 2006 on Citizenship of the Republic of Indonesia, Law of the Republic of Indonesia Number 13 of 2006 on the Protection of Witnesses and Victims and the Law of the Republic of Indonesia No. 21 Year 2007 on Combating the Crime of Trafficking in Persons. Dhia Al Uyun, SH. MH 'Women's Rights in Indonesian Constitution', (2014) 4, (8 (1) June)) International Journal of Humanities and Social Science 75.

18 Of these, around sixty laws were passed in 2013, which restricts a woman by interfering in every sphere of their life including morality, religious behavior, prohibiting women from going outside at night without male accompaniment. as it has not fully criminalized the practice of female genital mutilation. ${ }^{19}$

If we reflect on the impact of the Constitution on the gender justice aspect both the Indian and the Indonesian Constitution give due regard to equality among citizens. However the Indian constitution is more explicit in terms of its gender justice concerns. Indian constitution has incorporated a good number of provisions towards ameliorating the position and status of women. For example, due to the mandate of the Indian Constitutional provisions like Article 14, 15, 16, 23, 39, 43, and 46 various legislative measures for the protection of women workers are enacted. ${ }^{20}$ However, in Indonesia's case, there are no laws that protect domestic women workers who go to other countries for work, making them vulnerable to exploitation and working in poor work conditions posing health risks, trafficking, and other human rights exploitation. $^{21}$ In comparison, the Indian constitution makes far-reaching, special effects, and above all, explicit provisions for the upliftment of women that are somewhat missing in the Indonesian constitution under

19 The government banned the practice in 2006 but allowed some form of it in 2010 (No.1636/2010) to check unsafe genital mutilation practices.

20 Article 39 of the Constitution envisages that the state shall direct its policy, among other things, towards securing that there is equal pay for equal work for both men and women lead to the passing of the Equal Remuneration Act, 1976. Article 42 of the Constitution of India imposes an obligation upon the state to make provisions for securing just and human conditions of work and for maternity relief lead to the passing of the Maternity Benefit Act, 1961. Other such beneficial laws are the Workmen's Compensation Act, 1923; the Mines Act, 1952; the Payment of Wages Act, 1936; the Minimum Wages Act, 1948; the Factories Act, 1948; the Unorganised Workers Social Security Act, 2008.

21 Laws Curb Women's Rights in Indonesia, (2014) (14 February) Borgen Magazine, $<$ https://www.borgenmagazine.com/laws-curbwomens-rights-indonesia/> Accessed: 01-042020 . 
which the women's rights are written with a unisex approach.

\section{Gender Justice and Gender Violence Faced by Women in her Early Age}

Women in India and Indonesia face numerous varieties of violence during each stage of their life. At an early age, a girl child faces challenges including female foeticide, infanticide, sexual offences directed against children, and child marriage.

\section{Abortions}

Beginning with sex-selective abortions, it is a practice that has a deeprooted thought process at work. It is one of the worst and most heinous types of genderspecific violence. In India, the Medical Termination of Pregnancy Act, 1972, and the Prenatal Diagnostic Techniques (Regulation and Prevention of Misuse) Act 1996 are the two empowering Acts that protect the childbearing function of the woman and permit prenatal tests and abortions for specified reasons. However, the identification of the sex of the fetus and sexselective abortions are conducted with impunity. According to an estimated, around 6.7 million abortions are annually performed in India by illegal providers. It results in a high level of maternal morbidity and mortality. ${ }^{22}$ As a result, around 35 to 40 million girls are missing from the Indian population (census 2011). The sex ratios of girls to boys stand at 927 females per 1000 males in India. These skewed sex ratios indicate the failure of the management and

22 See G Sedgh, S Henshaw, S Singh, et al., Induced abortion: rates and trends worldwide, (Lancet Publications, 2007).

23 Laws Curb Women's Rights in Indonesia, (2014) (14 February) Borgen Magazine, < https://www.borgenmagazine.com/laws-curbwomens-rights-indonesia/> Accessed: 01-042020. implementation of the laws made to curb these practices. Due to widespread corruption, scarce awareness, lack of supervision of genetic and ultrasound clinics, there is an all-around lack of commitment and motivation to implement these laws.

Indonesian Constitution recognizes the sexual and reproductive health rights for women as a human right. However, enacting the other legislation and regulations has frustrated the constitutional effects by violating women's right to access health. Indonesia is a signatory to various international human rights instruments, but its compliance with contraception access is poor. The Committee on the Elimination of Discrimination against Women (CEDAW) in 2013 recommended ensuring a woman's access to birth control methods without her husband's consent and with more stress on law enforcement and capacity building of service provider. ${ }^{23}$ The Indonesian Penal Code 1982 criminalizes abortion services under its Article 346 to 349. The people indulging in educating, providing information or advice concerning contraception and abortion are criminalized with the punishment of four to fifteen years. Abortions are banned but millions of abortions are done each year. All this has resulted in unwanted pregnancies and unsafe abortions that exert detrimental effects on women's health. ${ }^{24}$ Indonesia legalizes sex selection using Assisted Reproductive Technology (ART) policy for restricted reasons. Government Regulation No. 61, along with Article 44, 2014 regarding

24 Executive Summary by the Indonesian Civil Society Coalition on Sexual and Reproductive Health and Rights <https://www.uprinfo.org/sites/default/files/document/indonesia/se ssion_27_-

_may_2017/js19_upr27_idn_e_main.pdf > Accessed: 15-08-2020. 
reproductive health, regulates this policy. Due to balanced bilateral kinship rules, sex selection are less however gender biases regarding birth and child mortality exist. The sex ratio of the entire population has also risen over the last thirty years, peaking at 101.2 males per 100 females in the 2010 population census. ${ }^{25}$

Thus in both countries, women face challenges regarding their reproductive rights. Women of both countries have limited rights over their bodies and choice about reproductive health and rights. In India, forced abortion, sex identification, and sexselective abortions are rampant, resulting in an alarming gender gap and the failure of the laws enacted for curbing these practices. As against this, Indonesia fares better in terms of sex selection due to balanced bilateral kinship rules except limited access to contraception.

\section{Sexual Crimes against Children}

As per the Indian National Crimes Records Bureau, crimes against children are also rising. The Protection of Children against Sexual Offences Act, 2012 was enacted to protect a child from sexual offences and sexual assault. The Act provides relief and rehabilitation provisions by making prompt provisions for a child's care and protection. The trials of these offences are done in special courts following speedy

25 Guilmoto Christophe Z., Is there a gender bias in births and child mortality in Indonesia? <https://www.niussp.org/article/gend er-bias-births-child-mortality-indonesiapeutparler-de-discrimination-sexuelle-en-indonesie/ > Accessed: 15-08-2020.

26 Analyzing the POSCO Act 2012, Times of India, April 25, 2013.

27 Female Child Labour in Indonesia, ILO Jakarta Newsletter: Give Girls a Chance End Child Labour (2009) $7 \quad$ (9 September) <http://www. ilo.org/jakarta/whatwedo/publications/langen/docName--WCM_041799/index.htm> Accessed: 5-05-2019. and sensitive child-friendly procedures. However, the lack of awareness about the provisions of this Act and mishandling of cases under it has lead to poor implementation and non-realization of benefits of the Act. ${ }^{26}$

For Indonesia, its one-third population comprises of children. According to an estimate, throughout Indonesia, around 40,000 to 70,000 children are victims of sexual exploitation. ${ }^{27}$ In 2010 around 2,046 reports of violence against children were made with 42 percent related to sexual violence. In 2012, the figure had risen to 2,637 cases with 62 percent of the sexual abuse cases. ${ }^{28}$ The trends between 2016 to 2019 continued to increase with 70 victims of child sexual abuse in 2017, 149 victims in 2018, and 1,200 reports about physical, psychological, or sexual abuse (between January to May 2019). ${ }^{29}$ The 2002 Child Protection Act in Article 4 grants the right to every child to enjoy life without violence and imposes a duty on the guardian or caretaker to protect him against any form of sexual exploitation, violence, and misconduct (Article 15). The first amendment in Article 9 grants the right to an education free from violence. The entire Article 76 concerns child, violence against him, forcing sexual intercourse, deceiving into obscene acts, trafficking, and sexual exploitation. ${ }^{30}$ As a party to World Congress

28 Child Rape in Indonesia a 'National Emergency' <https://www.kebijakankesehatanindonesia.net/3 1-berita/berita-internasional/884-child-rape-inindonesia-a-national-emergency> Accessed: 0209-2019.

29 Siddharta Amanda, Physical, Sexual Violence Against Children Surging in Indonesia, (2019) (4 August) <https://www.voanews.com/east-asiapacific/physical-sexual-violence-against-childrensurging-indonesia > Accessed: 11-3-2020.

30 All these prohibitions are criminalized under Articles 77B, 80-83, and 88 with a punishment of 3.5 years and $72,000,000$ rupiahs to 
III against Sexual Exploitation of Children and Adolescents (2008) in 2016, the Indonesian parliament passed laws authorizing chemical castration of offenders to deter would-be violators from committing these heinous acts. More stress is on increasing public awareness regarding sexual abuse among children. ${ }^{31}$

The cases of sexual violence and child sexual abuse are continually on the rise in both these countries. Despite these rising reported figures, it is believed that these figures are only the tip of the iceberg as there are countless unreported cases, and the exact figures will be much more. In terms of dealing with these sexual offences directed against children, India has established robust machinery and effective law to tackle the issue, but the lack of awareness about the provisions of this Act remains a challenge for both the countries who are undertaking awareness initiatives to bring the benefits to the children.

\section{Gender Justice and Gender Violence in Media, Trafficking, and Rape}

In their adulthood, women face violence in the form of indecent representation and stereotypical portrayal in media, trafficking and rape.

\section{Media}

Media is not only an important means of communication but is regarded as the guardian of the public interest that shapes young minds towards gender roles. However, the negative portrayal of women is on the rise. The general lack of sensitivity towards

a maximum of 15 years and 5,000,000,000 rupiahs.

31 Khidhir Sheith, Indonesia must protect its children, The ASEAN Post, (2020) (22 August) $<$ https://theaseanpost.com/article/indonesia-mustprotect-its-children> Accessed: 21-5-2020. this form of violence and non-astringent punitive action has led to portraying women as a commodity. In India, the Indecent Representation of Women (Prohibition) Act, 1986 prohibits any form of representation of women that is indecent through advertisements, books, and pamphlets. As per the meaning of the term under Section 2 of Act, 'Indecent representation of women' implies any form of the depiction of the woman in such a way that is indecent, derogatory, denigrating women, or is likely to deprave, corrupt or injure the public morality or morals. The Act does not adequately deal with the cases of electronic media, the internet, and mobile phones. Practically, the conviction rates are low, and the legal provisions are ineffectual. The interpretation of diverse sections leaves a lot to the subjectivity of the judges. ${ }^{32}$ Cybercrime against women is a relatively new form of gender violence. With the passing of the Information Technology Act, 2000, India gave stress on women's protection against cyber-stalking, cyber pornography, defamation, e-mail spoofing, harassment via e-mails, morphing, to name a few.

In the case of Indonesia, there is a gradual shift both locally and globally about the women's portrayal in her traditional role in media. The portrayal of an ideal woman, from sexual object to subservient with her role restricted to family life, is growing. ${ }^{33}$ This form of the negative and secondary portrayal of women in media causes an unfavorable impact on the efforts towards women empowerment. The

32 See cases AIR 1975 SC 1332, AIR 1965 SCR 881.

33 Nash Zakary, Portrayal of Women in Films, Soap Operas, The Jakarta Post, (2018) (6 March) <https://www.thejakartapost.com/life/2018/03/06/ portrayal-of-women-in-films-soap-operas.html> Accessed: 9-11-2019. 
Indonesian government is carrying out several activities to sensitize the stakeholders about gender issues through media orientation programmes and discussion, debates and dialogues on gender concerns. ${ }^{34}$

Media that includes components of the mass media and communications industry includes print media, news media, cinema, radio and television. In India, the laws are passed that protect the indecent representation of women but conviction rates are low thereby making the legal provisions ineffectual. The laws are half baked that don't do much to take care of the victimization of women in media and cyber space. The portrayal of women in Indonesia also leaves much to be desired. The unfavorable impact of these stereotypical portrayals hampers the efforts towards women empowerment and gender justice. As against this the Indonesian women still lack the tools to report the instances of cybercrimes and inadequate steps to handle such cases. Both the countries are making efforts and carrying out several activities to sensitize the stakeholders about gender issues.

\section{Trafficking}

Human Trafficking is a global menace that has its roots in every culture that includes India and Indonesia. UN Protocol to Prevent, Suppress and Punish Trafficking in Persons, Especially Women and Children 2000, defines "trafficking" as the recruitment, transportation, transfer, harboring or receipt

34 National report for the ten-year review and appraisal of the implementation of the Beijing Declaration and Platform for Action, (2004) <www.un.org/womenwatch/daw/Review/english/ responses.htm> Accessed: 7-7-2020.

35 Article 3 of the UN Protocol to Prevent, Suppress and Punish Trafficking in Persons, Especially Women and Children 2000.

36 Around 3 million prostitutes in India, UNODC, (2007) $4 \quad$ (8 $\quad$ May) <https://www.unodc.org/pdf/india/publications/In of persons through threat or use of force or other forms of coercion, abduction, fraud, deception or the giving or receiving of payment or benefit for having the control over the other person. ${ }^{35}$ India is emerging as the center for human trafficking and a safehaven for the traffickers. There are over 3 million female sex workers in India, with 35.47 percent of them entering the trade before the age of 18 years. ${ }^{36}$ It is one of the largest sex industry centers in Asia in which young girls get trapped with no escaping. The Immoral Traffic (Prevention) Act, 1987 deals with this form of violence that continues due to the lack of sensitivity and understanding of the dynamics of the sex trade and treating sex trafficking victims as immoral. There is a lack of service coordination between those engaged in curbing human trafficking. Rehabilitation and reintegration programs for those recovering from the sex trade are ineffective coupled with rejection from survivors who think that sex trade as the only means of survival for themselves and their families. $^{37}$

In Indonesia, migrant women workers face a higher risk of trafficking for sexual exploitation and up to $30 \%$ of all sex workers are under 18 years of age. ${ }^{38}$ It was from 1990 onwards that employment as sex workers and housemaids, mostly in foreign countries increased. These domestic women workers are at risk of being forced into prostitution. It resulted in women becoming the victim of various atrocities and getting infected with

dia\%20Country\%20Report.pdf> Accessed: 13-72020.

37 K Kempadoo and J Doezema, (ed), Global Sex Workers: Rights, Resistance, and Redefinition (New York : Routledge, 1998) 89.

38 T. Hull, G. Jones, and E. Sulistyaninsih, 'Prostitution in Indonesia' in Lin Lean Lim (ed.), The Sex Sector: the Economic and Social Bases of Prostitution in Southeast Asia (Geneva, Switzerland: ILO, 1998) 42. 
various sexually transmitted diseases. There are no laws to check these immoral practices except the Indonesian criminal code that prohibits the facilitation of illegal sexual activity under Article 296, the trade-in women under Article 297, and earning profits from prostitution under Article 506. The 2007 anti-trafficking law criminalized all forms of labor trafficking and sex trafficking of adults and prescribed penalties of three to fifteen years of imprisonment. On the flip side, the law requires demonstration of force, fraud, or coercion to constitute a child sex trafficking offense. Inconsistent with international law, it did not criminalize all forms of child sex trafficking. ${ }^{39} \mathrm{~A}$ report by the National Commission on Violence against Women (2019) confirms that women with disabilities suffer high from sexual violence (from 40 cases in 2015 to 89 cases in 2019). ${ }^{40}$

The Indian Constitution under Article 23 specifically bans the trafficking in persons. The Indian Penal Code, $1860^{41}$ along with other laws and related regulations deals with the various issues of trafficking in women and children. ${ }^{42}$ The Immoral Traffic (Prevention) Act, 1956 prevents trafficking

39 United States Department of State, trafficking in Persons Report - Indonesia, (2018) (28 June) < https://www.refworld.org/docid/5b3e0b1ca.html> Accessed: 04-07-2020.

40 Why Indonesia's anti-sexual violence bill important for people with disabilities, https://theconversation.com/why-indonesias-antisexual-violence-bill-important-for-people-withdisabilities-118045> Accessed: 14-08-2020.

41 Section 366A-procuration of a minor girl (below 18 years of age) from one part of the country to the another is punishable; Section 366B-importation of a girl below 2 years of age is punishable; Section 374- provides punishment for compelling any person to labour against his will.

42 Juvenile Justice Act, 2986 and 2000; Juvenile (Care and Protection of Children) Act, 2000; Cruelty to women (Deterrent Punishment) ordinance, 1983; Immoral Traffic (Prevention) Act, 1956; the Young Persons Harmful Publication Act, 1956; Indecent Representation of Women among women and children and its commercialization. $^{43}$ Despite so many beneficial laws in place, trafficking continues in India due to various complexities that include physical, psychological problems of survivors and political, economic, and institutional obstacles that hinder programs designed to assist survivors. Even the Indonesian Government fails has to a large extent unsuccessful in meeting the minimum standards for the elimination of trafficking. Though it is making efforts to investigate, prosecute and convict traffickers. The repatriation services are provided to Indonesian victims from overseas to reduce their vulnerability. But corruption, lack of familiarity with trafficking indicators and anti-trafficking laws impair proactive victim identification among vulnerable populations, hinders law enforcement efforts makes it complicated to deal with trafficking. ${ }^{44}$

\section{Rape}

Out of the many crimes prevalent in society, rape is one of the most heinous crimes because it's not just an attack on the

(Prohibition) Act, 1986; Children (Pledging of Labour) Act, 1933; Bonded Labour (Abolition)Act, 1976; Child Labour (Prohibition and Regulation) Act, 1976; Criminal Law (Amendment Act), 1986.

43 The Immoral Traffic (Prevention) Act, (ITPA) 1956, deals exclusively with trafficking, inhibits trafficking in women and girls for prostitution and declares various related acts as a punishable offence. The Act was passed in line with the International Convention for the Suppression of the Traffic in Persons and of the Exploitation of the Prostitution of Others, signed by India on May 9, 1950. Although the Act was amended twice (1978 and 1986), it did not prove to be an effective deterrent to trafficking or sexual exploitation for commercial purposes.

44 United States Department of State, Trafficking in Persons Report - Indonesia, (2018) (28 June) < https://www.refworld.org/docid/5b3e0b1ca.html> Accessed: 04-07-2020. 
body of the person but also the soul. ${ }^{45}$ The Indian Penal Code, 1860 and Criminal Law Amendment Act, $2013^{46}$ deals with the crime of rape, and makes it a punishable offence. Despite the presence of strict legal provisions, rape offences are consistently rising. ${ }^{47}$ Rape is the worst form of crime against women and around 93 Indian women are raped every day. ${ }^{48}$ According to the National Crime Records Bureau, a new case of rape reported every 22 minutes. ${ }^{49}$ Despite changed attitude, society at large attaches a stigma to the rape survivor, blames her, and does character assassination of the victim woman instead of castigating the perpetrator. ${ }^{50}$ Despite Section 114A in the Indian Evidence Act, 1872 that raises a presumption as to the absence of consent in certain prosecutions for rape, the conviction rates remain low.

If we consider the prevalence of this form of violence in Indonesia, a study conducted by the United Nations Multicountry Study at different locations in Indonesia found the prevalence of rape (19.5 percent) and gang rapes ( 7 percent). ${ }^{51}$ The rape rate fell from 1.1 cases per 100,000 populations in 2009 to 0.7 cases per 100,000 populations in $2015 .{ }^{52}$ Around $93 \%$ of rape

45 Naresh Pareek, and Kunal Kumbhat, 'Death penalty for rape: Is it feasible?' (2005) (July, Vol. 111) Criminal Law Journal 219-222.

46 The Criminal Law Amendment Act, 2013 has increased the list of crimes against women and has made rape and crimes against women more stringent and women sensitive. All these forms of violence are a reflection of the way society treats women as a commodity or an object.

47 Rape cases in India have doubled between 1990 and 2008, Crime in India 2012, National Crime Records Bureau, Government of India.

48 '93 women are being raped in India every day', NCRB data show, Times of India <https://timesofindia.indiatimes.com/india/93women-are-being-raped-in-India-every-dayNCRB-data-show/articleshow/37566815.cms> Accessed: 1-08-2020.

49 See National Crimes Record Bureau, Crime in India Reports, Statistics Government of India. victims did not file complaints fearing being blamed and just one percent of cases ended in conviction. ${ }^{53}$ Article 258 of the penal code defines rape and provides penalties funder Articles 286-288. Very few cases are agitated in the court due to the lesser punishment given to the offenders. Ironically the provision of mediation, payment of fines towards the settlement and the practice of allowing marriage between the victim and the rapist frustrate the provisions of the law by normalizes the gruesome act of rape against women. ${ }^{54}$

Thus despite the presence of strict legal provisions, rape offences in India are consistently rising. The situation is no better in Indonesia. Due to stigma, fear of the system, and poor conviction rates, rape complaints are hardly lodged. Importantly, marital rape that is not recognized in India is also not a criminal offence under the penal code but prohibited under the Elimination of Domestic Violence Law 23/2004 in its various Articles.

\section{Gender Justice, Gender Violence and Marriage Laws}

50 Radha Kumar, The History of Doing: An Account of Women's Rights and Feminism in India (India: Zubaan, 1993) 128.

51 Why Do Some Men Use Violence Against Women and How Can We Prevent It? (UNDP, UNFPA, UN Women and UNV, September 2013) 40.

52 Indonesia Rape Rate <https://knoema.com/atlas/Indonesia/Rape-rate> Accessed: 15-07-2020.

53 Saraswati Putri Widi, Indonesia Needs to Address Its Rape Culture Problem $<$ https://www.vice.com/en_asia/article/vvgyxx/in donesia-needs-to-come-to-terms-with-its-rapeproblem> Accessed: 15-08-2020.

54 CEDAW Concluding observations of the Committee on the Elimination of Discrimination against Women CEDAW/C/IDN/CO/6-7, (2012) 7 <http://tbinternet.ohchr.org/_layouts/TreatyBody External/Countries.aspx?CountryCode=IDN\&La ng=EN Accessed on: 09-06-2020. 
A married woman faces domestic violence, dowry demands, and various other forms of matrimonial offences.

\section{Child Marriage}

Child marriage is yet another phenomenon that is widely practiced in both countries. ${ }^{55}$ It is a grave and systematic form of abuse towards young girls and violates their several international human rights. Early marriages are the reason behind poor health, poor education, and poor growth of the personality of women. ${ }^{56}$ The crime record shows the pervasiveness of this practice. In India, the Child Marriage Restraint Act 1929 and the Prohibition of Child Marriage Act 2006 prohibits the solemnization of child marriages (preamble and section 15). They are legally voidable at the option of the party who was a child at the time of the marriage. As per statistics, $45 \%$ of Indian women are married before they reach the legal age of marriage in India ie: eighteen years. ${ }^{57}$ The percentage of child marriage is much higher in rural areas (58.5 percent) as compared to urban areas (27.9 percent). ${ }^{58}$ As a social phenomenon, child marriage has deep roots in the Indian social fabric that requires additional support apart from legislative interventions. Registration of marriage provided under Indian laws for substantially curbing the practice of child marriages is not strictly enforced. ${ }^{59}$ Poverty, gender inequality, discrimination and poor access to education for girls are the reasons behind the

55 Bharti Dalbir, Women and the Law (New Delhi: APH Publishing Corporation, 2008)24.

56 Alka Barua (et.al.), 'Care and Support of Unmarried Adolescent Girls in Rajasthan’, (2007) XLII (44) Economic and Political Weekly 54.

57 Anahita Mukherji, ' $47 \%$ of young Indian women marry before 18', The Times of India, May10, 2011, p. 10.

58 National Family Health Survey of 2005-2006 (NFHS- continuance of these early marriages. Child marriage leads to poor life skills among young brides and they experience violence and abuse within such marriages.

The practice of early marriage is also widespread in Indonesia, especially in rural areas. Indonesia's Law No.1 of 1974 on Marriage Law permits girls to marry at the age of 16 . Around $14 \%$ of the girls marry below this age and $1 \%$ of them marry even before the age of 15 . There is no deadline and transparency about the abolition of these early marriages ${ }^{60}$ that are the prime reason behind maternal mortality of above 200 per 1000 live births in the past decade. ${ }^{61}$

Hence child marriages with all its negative effects like maternal mortality are pervasive in both countries, especially in their rural areas. For Indian girls, the age of marriage is slightly high (18 years) as compared to Indonesian law that permits girls to marry at the age of 16 years. Both countries recognize child marriages but Indian laws prohibit them and make them voidable under certain circumstances. Nevertheless, none of these countries have so far taken any positive step towards declaring them as absolutely void or for their complete abolition.

\section{Domestic Violence and Dowry}

Yet another barrier towards women empowerment is the phenomenon of domestic violence, particularly in the matrimonial home that is regarded as a

3), http://www.rchiips.org/nfhs/nfhs3.shtml, > Accessed: 07-12-2019.

59 B S Negi, Child Marriage in India (New Delhi: Mittal Publications, 1993) 9.

60 Human Rights Watch, Indonesia Events of 2018 <https://www.hrw.org/worldreport/2019/country-chapters/indonesia> Accessed: 30-06-2020.

61 UNFPA Indonesia Monograph Series: No.5 Women and Girls in Indonesia: Progress and Challenges (UNFPA Indonesia, 2015) 2. 
private space. In India, the Protection of Women from Domestic Violence Act, 2005 provides a civil law remedy to protect women in an abusive, violent relationship and subjected to any act of domestic violence. But due to the traditional conservative value system, family members either refrain or discourage women victims from registering case under this law. Stigma is attached to reporting these cases in the police station in the garb of family reputation and prestige. ${ }^{62}$

Apart from domestic violence, dowry is one of the social evils that lead to exploitation, harassment, and violence against Indian women in case their family fails to provide sufficient dowry. ${ }^{63}$ There is a steep rise in cases related to dowry that continues unabated. ${ }^{64}$ Dowry or bride price prevails in India that leads to exploitation and harassment of a woman if she brings insufficient dowries or "groom price". ${ }^{65}$ To prohibit the demanding and give and take of dowry, the Dowry Prohibition Act, 1961, makes it a punishable offence, but the law is poorly implemented, hardly any cases are filed under this Act and if filed the convictions rate is low. The absurd interpretation of the Act defeats the very spirit and purpose of this enactment due to which it has failed to set any deterrent effect in the minds of the perpetrators.

Further, the Indian Penal Code, 1860 defines matrimonial offences under Chapter XX (Section 493-498) and Chapter XX-A (Section 498A) that was added by the

62 Chetan Chauhan, 'Domestic Violence Act- Will Law Go the Dowry Act Way? No System in Place Yet', Women's Link (2007) 13 (No.1. JanuaryMarch).

63 In 2010, 8,391 dowry death cases were reported across India, meaning a bride was burned every 90 minutes, National Crimes Record Bureau, Crime in India 2012, Government of India.

${ }^{64}$ Kundula Bala Subrahmanyam v. State of Andhra Pradesh, AIR 1997 SCC 3011.
Criminal Law (Second Amendment) Act 1983. These sections deal with cruelty against women, bigamy (section 494 and 495), and adultery (section 497). Nonetheless, husband deserting their first wife and marrying again persists and social pressures, stigma and economic compulsions force the women victim to keep quiet. It is often difficult for the wife to prove the fact of the solemnization of a second marriage. Legal hurdles in accessing justice add to the woes of uneducated and un-empowered women. ${ }^{66}$

Indonesian follows a non-tolerance policy regarding violence against women. ${ }^{67}$ The Law on Domestic Violence (2004), the Victim Protection Law (2006) and the Law on Anti-Trafficking (2007) deals with this aspect. The Marriage Act of 1974 discriminates against women by placing men as household head, permits polygamy, and keeping the legal age for a girl's marriage low. Matrimonial laws in Indonesia are guided by the civil, customary, and Sharia (Islamic) laws that are based on the religion of the person under which one is registered. The Law No. 1 of 1974 on Marriage and the compilation of Islamic law in Indonesia lay down the legal standards for governing marriage and divorces. Both men and women enjoy equal rights under Article 6 of the 1974 Marriage Law and require every marriage to be registered that is not registered. A strict form of Sharia law exists in some provinces that are discriminatory to women. ${ }^{68}$

65 Sushil Kumar Sharma v. Union of India and others, 2005(5) SC 71.

66 Roma Mukherjee, Legal Status and Remedies for Women in India (New Delhi: Deep \& Deep Publications, 1997).

67 Jack, and Tambiah, S.J., Bride Wealth and Dowry (Cambridge: Cambridge University Press, 1973)17.

68 CEDAW Concluding observations of the Committee on the Elimination of Discrimination against Women CEDAW/C/IDN/CO/6-7 (2012) 
Article 1 of the Law on Domestic Violence (2004) defines domestic violence and prescribed criminal penalties against it in Chapter VIII. There is a general lack of gender awareness among law enforcement agencies leading to weak implementation of domestic violence laws. Domestic violence is poorly documented and underreported because it is regarded as a private matter. ${ }^{69}$ Crisis services are often not available in rural areas. Women are seeking redressal view the entire process of seeking justice as lengthy, complicated, and ineffective. ${ }^{70}$

Comparatively, due to lack of awareness, domestic violence laws in Indonesia are not effectively utilized, whereas the Indian domestic violence act is quite effectively used to tackle gender violence. Women in both countries face bigamy and adultery but again, the situation of women in India is better as bigamy, ${ }^{71}$ and adultery can be a ground for seeking divorce under every personal law. ${ }^{72}$ In India, dowry demand continues that leads to exploitation, harassment, and violence against Indian women. But the dowry act has failed to set any deterrent effect in the minds of the perpetrators. To a large extent, dowry demands are not widespread in Indonesia as women have inheritance rights in land and assets and freedom to decide the choice of the matrimonial home. Non-registration of

68 $19<$

http://tbinternet.ohchr.org/_layouts/TreatyBodyE xternal/Countries.aspx ?CountryCode $=$ IDN\&Lang $=\mathrm{EN}>$ Accessed on 21-04-2020.

69 US Department of State, 2016 Country Reports on Human Rights Practices: Indonesia, Washington, DC

(2016) https://www.state.gov/j/drl/rls/hrrpt/2016/ eap/265338.htm > Accessed on 02-05-2020.

70 CEDAW Consideration of reports submitted by States parties under article 18 of the Convention on the Elimination of All Forms of Discrimination against Women Combined sixth and seventh periodic reports of States parties Indonesia, marriage in both these countries persists that deprives women of their legal entitlements in case of need. Despite these facts, access to justice remains a challenge for women in both countries. They face countless impediments in terms of social stigma, fear of police and legal machinery, costly, long, and cumbersome legal battles, to name a few.

\section{Gender Justice, Gender Violence and Women at the Workplace}

Women at the workplace face numerous problems ranging from problems of security, sexual harassment, safety concerns, wage disparities, non-payment of wages, non-satisfactory childcare facilities, to name a few. All these problems are common to both India and Indonesia. If we look at the workplace from the gender justice perspective, India has undertaken various social changes towards women's education and economic development that have contributed to their independence and progress of women in Indian society. They are now shouldering new responsibilities, both at home and work front. As per the National Sample Survey Office reports, women's work participation rate for the year 2017-2018 stands at 23.3 percent. Thus women are gradually coming out of their

CEDAW/C/IDN/6-7, CEDAW, New York (2011) p. 68,19

$<$ http://tbinternet.ohchr.org/ layouts/TreatyBody External/Countries.aspx?CountryCode=IDN\&La ng=EN $>$ Accessed on: 20-7-2020.

71 Under the Hindu Marriage Act, 1955; Section 5(i) prohibits bigamy; Section 11 makes a bigamous marriage void and Section 17 makes it a penal offence under Sections 494 and 495 of the Indian Penal Code, 1860.

72 Under the Indian legal system, personal laws direct and control the relations within the family and marriage and are specific to each community. 
homes and making economic contributions but not without challenges. ${ }^{73}$

India has enacted various protective laws for women in the workplace. If we look at National Sample Survey Office reports, out of the total 46.5 crores workforce in India, around 2.8 crores are employed in the organized sector and 43.7 crores in the unorganized sector. Every unorganized sector is typified by low wages, poor living standards, long working hours, hazardous working conditions, etc. The Unorganized Workers' Social Security Act, 2008 affirms and promotes principles of equality and equity for women. This Act is the first of its kind that regulates the unorganized sector and the plight of domestic women workers by providing social security to them. Realistically, this law remains ineffective as the majority of the workforce employed in the unorganized sector is unable to reap the complete benefits of this advantageous Act. ${ }^{74}$ It has shown dismal progress as minimum social security standards enforceable by law are not defined and the institutional powers to ensure effective implementation of its provisions are not detailed.

Another common workplace-related issue is the sexual harassment of women at her workplace that is violative of the right to work with dignity. This form of harassment can take the shape of unwelcome sexual conduct. It was in 1997 that the Indian case of Vishaka v. State of Rajasthan, AIR 1997 SC. 3011 laid guidelines to deal with this

73 Rukmini S, India's Workforce is Masculinizing Rapidly

<https://www.livemint.com/news/india/india-sworkforce-is-masculinising-rapidly1560150389726.html> Accessed: 05-08-2020.

74 Bhasin, Alok, Labour Laws-A Primer (Lucknow: Eastern Book Company, 2011) 148.

75 Ayesha Kidwai, 'Sexual Harassment in the Workplace, The Verma Committee and After', (2013) 48 (6) Economic and Political Weekly. variety of violence. Later, the Sexual Harassment of Women at Workplace (Prevention, Prohibition and Redressal) Act, 2013 defined sexual harassment at the workplace. The Act provides a redressal mechanism to deal with complaints filed by aggrieved women. Practically, in case of initiation of redressal proceedings, women are often harassed and pressurized to either leave their employment or relocate to other office branches. There has been a threat perception of women losing a job if they dared to complain, especially in cases where the culprit happens to be the employer. ${ }^{75}$

Additional Labour laws like the Maternity Benefits Act, 1961, the Equal Remuneration Act, 1976, and Minimum Wages Act protects Indian women workers. The Maternity Benefits Act, 1961 regulates employment conditions of women laborers employed in factories by making provisions for crèches and sanitation. ${ }^{76}$ However, employers negate these conditions, and women workers lack awareness about these benefits. The Equal Remuneration Act, 1976 was enacted for providing payment of equal remuneration to women workers devoid of gender-based discrimination. None of these Acts are effectually implemented as employers re-classify the jobs to avoid payment of similar wages. ${ }^{77}$

In the case of Indonesia, it was after the large scale multinational investments during the 1970s that the Indonesian women joined the workforce as cheap labourers in manufacturing units. The number of male

76 Government of India, Report on the Working of the Maternity Benefit Act, 1961 during the Year 2008

<http://labourbureau.nic.in/Report_MB_Act_200 8.pdf > Accessed: 06-10-2019.

77 Nivedita Menon, Themes in Politics Gender and Policies in India (New Delhi: Oxford University Press, 1999) 26-27. 
versus female labour participation is 67,944,695: $40,186,363$ and the rate of average salaries is $1,141,308$ rupiahs: 854,052 rupiahs for the same work. ${ }^{78}$ They hold $33 \%$ of non-agricultural employment. ${ }^{79}$ As per the 2000 census, women account for $47 \%$ of the workforce (excluding women working from home, doing piece work, selling in the market, etc.). In 2018, there is an increase of 55.4 percent in the labor force participation of women.

Thus women are growingly entering the Indonesian labour market but have a lower participation rate and continue to be either unemployed, have poor wages and face inequality in work and promotion with inadequate access to resources making them vulnerable to both personal and financial insecurities. For women, the workplace remains a non-friendly site. The related laws are not entirely enforced and women hardly report these cases to authorities fearing dismissal from the job. ${ }^{80}$ Law $13 / 2003$ provides similar opportunities to get a job without any discrimination under Article 5 and equal treatment from the employer under Article 6. But there is no clarity about the non-discrimination based on sex. There is no law on equal pay for equal work, though maternity leaves are granted under Article 82. Companies often try to evade these requirements by hiring women as day labourers and not as full-time employees, pregnant women workers are made to resign and domestic workers are denied any such protections. ${ }^{81}$ Despite its widespread

78 Dhia Al Uyun, above n. 17, 75.

79 'Share of women employed in the nonagricultural sector (\% of total non-agricultural employment)', The World Bank < https://tcdata360.worldbank.org/indicators/37a4b 818 ? country $=$ BRA\&indicator $=28111 \&$ viz $=$ line_c hart\&years=1990,2013> Accessed: 21-09-2019.

80 Indonesia: Sexual harassment \& discrimination of women remain high despite increased labour force participation prevalence, there is no separate legal provision to deal with sexual harassment. Only, the penal code under Article 281 defines 'indecent public act' and makes volitions of this article a punishable act. As per the Human Rights Watch report of 2017, the women facing harassment are often not forthcoming. Above that, the local by-laws pass on the blame of sexual harassment on the victim.

Thus women at the workplace women face sexual harassment, inequality, and discrimination that deny several rights. Pertinent laws for preventing sexual harassment are crucial for women's sustenance and dealing with other workplace associated problems. Due to changed economic and educational attainments along with a huge number of laws enacted for protecting women, they are gradually coming out of their homes and are making economic contributions to their respective countries. Statistically, women in both countries are growingly entering the labour market but the concerned laws are ineffective as the majority of the workforce employed in the unorganized sector. Even the employers try to steer clear of the effect of these beneficial laws by either reclassifying jobs, showing resistance in hiring women for their core jobs, and pressurizing women to refrain from complaining against the wrongs suffered by them at the workplace. India sill fares better in terms of enacted laws for equal pay for equal work, protecting women against sexual harassment, and maternity benefits to women

<https://www.business-humanrights.org/en/latestnews/indonesia-sexual-harassmentdiscrimination-of-women-remain-high-despiteincreased-labour-force-participation/ > Accessed: 10-02-2020.

81 US Department of State, '2016 Country Reports on Human Rights Practices: Indonesia', Washington, $\mathrm{DC}$

(2016) https://www.state.gov/j/drl/rls/hrrpt/2016/ eap/265338.htm > Accessed on 02-05-2020.

156 | Tyagi - Gender Violence, Gender Justice, and Gender-Based Laws... 
in unorganized sectors. For both the counties, to close the existing workforce gender participation gaps the focus should be directed on equal employment opportunities, women's training, skill development, segmentation, and covering of wage gaps. ${ }^{82}$

\section{CONCLUSION SUGGESTION}

AND

Considering the data on the status of women in India and Indonesia, it is proved that women are generally treated with apathy, indifference, and discrimination. Women, in general, have been denied their due rights in every stage of their life. When we look at women working shoulder to shoulder with their male counterparts, we get an impression of equality. In reality, women continue to suffer in the absence of real analysis of their problems. Constitutional provisions and the legislation enacted by both the Government of India and the Government of Indonesia aims to safeguard the interests of women. Several women-centric legislations are bringing slow but active change in the social, economic, and political status of women in these two countries. However, stringent efforts are required towards laying a strong foundation for gender justice and women empowerment. Both these countries do not secure all the rights of women due to diverse reasons.

Early marriages are unchecked in both countries, and both are working towards awareness generation and curbing them. There is a tendency of non-reporting of child sexual abuse and rape cases. The governmental efforts are now directed at providing a safe environment for victims with thrust on sensitive handling of this gender-specific violence. India is gradually

82 Global Network for Advanced Management, What are the Obstacles to Women in the Global Workforce? progressing towards addressing child sexual abuse cases. Both countries are finding ways to improve both the content and enforcement of these laws. As a party to several womencentric conventions, both India and Indonesia are working towards these commitments and incorporating them in their respective national legislation. In this regard, again, India is fairing far better than Indonesia, evident from the host of laws it has enacted for women. India is planning to increase the age of marriage to 21 years from the current 18 years under its marriage laws. Stringent punishments are prescribed for the solemnization of early marriages. A lot of initiatives and awareness generation programs launched in India about the harmful effects of early marriages and maternal mortality are effective.

Further, the brief survey of statistics on the prevalence of domestic violence laws, it is discernible that there is a need for addressing it. We need to deal with the reasons behind domestic violence that will include the evaluation of poverty, gender discrimination apart from providing equal access to education for girls. There is a need to develop support systems for girls who are married and are experiencing violence and abuse within marriage. To help victims of domestic violence and sexual abuse, Police Officers need to take immediate action. Delays in filing the police reports should not stop the course of the investigation of a crime. Deployment of police forces is crucial as the same can prevent the happening of crimes related to violence against women.

Health and reproductive rights is yet another area of consideration. There is a need for greater involvement of the medical community by banning all kinds of

<https://globalnetwork.io/perspectives/2017/03/w hat-are-obstacles-women-global-workforce>

Accessed: 02-08-2020. 
commercial use of sex-selective techniques. The Government must create the machinery to implement these laws and for educating its officers and stakeholders about its provisions and implications. Awareness generation among women about the laws with a thrust on women's education will increase their voice in decision-making and participation in society.

The statistics prove that young girls from both countries receive a poor education, face violence, discrimination, and have low women workforce participation rates. Women face workplace-related issues, including lower wages, poor work conditions, and rampant sexual harassment. The need is to make labour laws nondiscriminatory. Retention policies should ensure equal pay for equal work, minimum wage, maternity protection, and prevent sexual harassment at the workplace. Speedy, stringent remedy can check the issue of sexual harassment with a focus on ensuring that any affirmative action is not detrimental to women and their employment prospects.

Therefore, the women related issues must be considered with gravity as well as sensitivity. Complete women empowerment and gender justice will not be achieved just by making gender-based laws, rules, policies and regulations. There should be constant monitoring of their implementation through regular research and studies. Appropriate steps should be undertaken to curbing the prevailing discriminatory practices. There should be thrust on changing the feeble situation of women in both these countries. This can be achieved by the active and honest participation of all the concerned parties. Lastly, it is crucial to create awareness about women empowering laws and policies to bring gender justice for women of these two countries.

\section{REFERENCES}

\section{Books}

Alok, Bhasin, Labour Laws - A Primer (Lucknow: Eastern Book Company, 2011)

Dalbir, Bharti, Women and the Law (New Delhi: APH Publishing Corporation, 2008)

Daniel Mc, Offering Flowers, Feeding Skulls: Popular Goddess Worship in West Bengal, (Oxford University Press, 2004)

G., Sedgh (et.al.), Induced abortion: rates and trends worldwide, (Lancet Publications, 2007).

Hull T. (et.al.), 'Prostitution in Indonesia' in Lin Lean Lim (ed.), The Sex Sector: the Economic and Social Bases of Prostitution in Southeast Asia (Geneva, Switzerland: ILO, 1998).

Jack, and Tambiah, S.J., Bridewealth and Dowry (Cambridge: Cambridge University Press, 1973)

Julia, Leslie, The Perfect Wife: The Orthodox Hindu Women (Oxford University Press, 1989) 3-20.

Kempadoo. K. and Doezema J., (ed), Global Sex Workers: Rights, Resistance, and Redefinition (New York: Routledge, 1998)

Radha, Kumar, The History of Doing: An Account of Women's Rights and Feminism in India (India: Zubaan, 1993).

Nivedita, Menon, Themes in Politics Gender and Policies in India (New Delhi: Oxford University Press, 1999).

Roma, Mukherjee, Legal Status and Remedies for Women in India (New Delhi: Deep \& Deep Publications, 1997).

S., Negi B., Child Marriage in India (New Delhi: Mittal Publications, 1993). 


\section{Reports}

UNFPA Indonesia Monograph Series: No.5

Women and Girls in Indonesia:

Progress and Challenges (UNFPA Indonesia, 2015) 2.

Violence against women. In: Women in South

East Asia: A health profile, (New

Delhi, WHO regional office for South

East Asia, 2000) 147-60.

Why Do Some Men Use Violence Against

Women and How Can We Prevent It?

(UNDP, UNFPA, UN Women and

UNV, September 2013) 40.

\section{Journal}

Alka, Barua (et.al.), 'Care and Support of Unmarried Adolescent Girls in Rajasthan', (2007) XLII (44) Economic and Political Weekly 54.

Ayesha, Kidwai, 'Sexual Harassment in the Workplace, The Verma Committee and After', (2013) 48 (6) Economic and Political Weekly.

Chetan, Chauhan, 'Domestic Violence ActWill Law Go the Dowry Act Way? No System in Place Yet', (2007) (No.1. January-March), Women's Link 13.

Pareek, Naresh and Kumbhat, Kunal, 'Death penalty for rape: Is it feasible?' (2005) (July, Vol. 111) Criminal Law Journal 219-222.

Robinson, Kathryn May and Bessell Sharon, 'Women in Indonesia: Gender, Equity and Development', (2002) 8 dari Indonesia assessment series, Institute of Southeast Asian Studies, 5.

Suryani, Luh Ketut, 'Balinese Women in a Changing Society' (2004) Vol. 32 The Journal of the American Academy of Psychoanalysis and Dynamic Psychiatry 217.

Uyun, Dhia Al, SH. MH 'Women's Rights in Indonesian Constitution', (2014) 4,
(8(1) June)) International Journal of Humanities and Social Science 75.

\section{Newspaper}

Anahita, Mukherji, ' $47 \%$ of young Indian women marry before 18', The Times of India, (2010) (May10) 10.

Devina, Heriyanto, "Indonesia ranked second-most dangerous place for women in Asia Pacific: Study" The Jakarta Post, Jakarta (2019) (March 6) $<$ https://www.thejakartapost.com/new s/2019/03/06/indonesia-rankedsecond-most-dangerous-place-forwomen-in-asia-pacific-study.html> Accessed: 29-10-2020.

Khidhir, Sheith, Indonesia must protect its children, The ASEAN Post, (2020) (22 August)

https://theaseanpost.com/article/indon esia-must-protect-its-children> Accessed: 21-5-2020.

Nash, Zakary, Portrayal of Women in Films, Soap Operas, The Jakarta Post, (2018) (6 March) <https://www.thejakartapost.com/life/ 2018/03/06/portrayal-of-women-infilms-soap-operas.html> Accessed: 911-2019.

Pallavi, Aiyar, 'Spot the similarities: unity in diversity in India and Indonesia', (2017) (August 29) <https://www.thehindu.com/opinion/o p-ed/spot-the-

similarities/article19576750.ece> Accessed: 29-10-2020.

S., Aritonang Margareth, "Survey finds widespread violence against women", The Jakarta Post Jakarta, (2017) (March <https://www.thejakartapost.com/new s/2017/03/31/survey-findswidespread-violence-againstwomen.html > Accessed: 29-10-2020. 
S., Rukmini, India's workforce is masculinizing

rapidly

$<$ https://www.livemint.com/news/indi a/india-s-workforce-is-masculinisingrapidly-1560150389726.html>

Accessed: 05-08-2020.

'93 women are being raped in India every day', NCRB data show, Times of India $<$ https://timesofindia.indiatimes.com/i ndia/93-women-are-being-raped-inIndia-every-day-NCRB-datashow/articleshow/37566815.cms>

Accessed: 1-08-2020.

\section{Acts}

The Constitution of India, 1950

The 1945 Constitution of the Republic of Indonesia

The 2002 Child Protection Act

The Child Marriage Restraint Act 1929

The Criminal Law Amendment Act, 2013

The Equal Remuneration Act, 1976

The Immoral Traffic (Prevention) Act, 1987

The Indecent Representation of Women (Prohibition) Act, 1986

The Indian Penal Code, 1860

The Indonesian criminal code, 1931

The Indonesian Penal Code, 1982

The Law on Anti-Trafficking (2007)

The Law on Domestic Violence, 2004

The Marriage Act of 1974

The Maternity Benefits Act, 1961

The Medical Termination of Pregnancy Act, 1972 ,

The Minimum Wages Act, 1948

The Pre-natal Diagnostic Techniques (Regulation and Prevention of Misuse) Act 1996

The Prohibition of Child Marriage Act 2006

The Protection of Women from Domestic Violence Act, 2005

The Protection of Children against Sexual Offences Act, 2012
The Sexual Harassment of Women at Workplace (Prevention, Prohibition and Redressal) Act, 2013

The Victim Protection Law, 2006

\section{Internet}

'Share of women employed in the nonagricultural sector ( $\%$ of total nonagricultural employment)', The World Bank

<https://tcdata360.worldbank.org/indi cators $/ 37 \mathrm{a} 4 \mathrm{~b} 818$ ? country $=$ BRA\&indic ator $=28111 \&$ viz=line_chart $\&$ years $=1$ 990, 2013> Accessed: 21-09-2019.

'Around 3 million prostitutes in India', UNODC, (2007) 4 (8 May) $<$ https://www.unodc.org/pdf/india/pub lications/India\%20Country\%20Report .pdf> Accessed: 13-07-2020.

'CEDAW Concluding observations of the Committee on the Elimination of Discrimination against Women CEDAW/C/IDN/CO/6-7' (2012)< http://tbinternet.ohchr.org/_layouts/Tr eatyBodyExternal/Countries.aspx?Cou ntryCode=IDN\&Lang=EN $>$ Accessed on 21-04-2020.

Child Rape in Indonesia a 'National Emergency'

$<$ https://www.kebijakankesehatanindo nesia.net/31-berita/beritainternasional/884-child-rape-inindonesia-a-national-emergency> Accessed: 02-09-2019.

Executive Summary by the Indonesian Civil Society Coalition on Sexual and Reproductive Health and Rights $<$ https://www.upr-

info.org/sites/default/files/document/in donesia/session_27_-

_may_2017/js19_upr27_idn_e_main.p df > Accessed: 15-08-2020.

Female Child Labour in Indonesia, ILO Jakarta Newsletter: Give Girls a 
Chance End Child Labour (2009) 7 (9

September)

$<$ http://www.

ilo.org/jakarta/whatwedo/publications/

lang-

-en/docName--

WCM_041799/index.htm> Accessed: 5-05-2019.

Global Network for Advanced Management, What are the Obstacles to Women in the Global Workforce? $<$ https://globalnetwork.io/perspectives /2017/03/what-are-obstacles-womenglobal-workforce> Accessed: 28-062020.

Government of India, Report on the Working of the Maternity Benefit Act, 1961 during the Year 2008 <http://labourbureau.nic.in/Report_M B_Act_2008.pdf > Accessed: 06-102019.

Guilmoto, Christophe Z., Is there a gender bias in births and child mortality in Indonesia

? < https://www.niussp.org/article/gen der-bias-births-child-mortalityindonesiapeut-parler-dediscrimination-sexuelle-en-indonesie/ > Accessed: 15-08-2020.

Human Rights Watch, Indonesia Events of $2018<\mathrm{https}$ ://www.hrw.org/worldreport/2019/country-

chapters/indonesia> Accessed: 30-062020.

Indonesia

Rape

Rate

$<$ https://knoema.com/atlas/Indonesia/

Rape-rate> Accessed: 15-07-2020.

Indonesia: Sexual harassment \& discrimination of women remain high despite increased labour force participation <https://www.businesshumanrights.org/en/latest-

news/indonesia-sexual-harassmentdiscrimination-of-women-remainhigh-despite-increased-labour-forceparticipation/ > Accessed: 10-02-2020.
Laws Curb Women's Rights in Indonesia, (2014) (14 February) Borgen Magazine, $<$ https://www.borgenmagazine.com/la ws-curb-womens-rights-indonesia/> Accessed: 01-04-2020.

Meiwita, Budiharsana, Female circumcision in Indonesia: extent, implications and possible interventions to uphold women's health rights, Population Council, Jakarta (2004) < https://knowledgecommons.popcounci 1.org/cgi/viewcontent.cgi ?article $=1033$ $\&$ context=departments_sbsr-rh> Accessed: 27-07-2019.

National Family Health Survey of 2005-2006 (NFHS-3)

<http://www.rchiips.org/nfhs/nfhs3.sht ml> Accessed: 07-12-2019.

'National report for the ten-year review and appraisal of the implementation of the Beijing Declaration and Platform for Action', <www.un.org/womenwatch/daw/Revi ew/english/responses.htm> Accessed: 07-07-2020.

Sankari, Rathina, 'World's largest matrilineal society', (2016) (22 September) < http://www.bbc.com/travel/story/20 160916-worlds-largest-matrilinealsociety> Accessed: 23-06-2020.

Saraswati, Putri Widi, Indonesia Needs to Address Its Rape Culture Problem $<$ https://www.vice.com/en_asia/articl e/vvgyxx/indonesia-needs-to-come-toterms-with-its-rape-problem> Accessed: 15-08-2020.

Siddharta, Amanda, Physical, Sexual Violence Against Children Surging in Indonesia, August) <https://www.voanews.com/e ast-asia-pacific/physical-sexualviolence-against-children-surgingindonesia > Accessed: 11-03-2020. 
United States Department of State, 'Trafficking in Persons Report Indonesia', (2018) (28 June) < https://www.refworld.org/docid/5b3e0 b1ca.html> Accessed: 04-07-2020.

US Department of State, '2016 Country Reports on Human Rights Practices: Indonesia', Washington, DC (2016) https://www.state.gov/j/drl/rls/ hrrpt/2016/eap/265338.htm >

Accessed on 02-05-2020.

Why Indonesia's anti-sexual violence bill important for people with disabilities, https://theconversation.com/whyindonesias-anti-sexual-violence-billimportant-for-people-with-disabilities118045> Accessed: 14-08-2020. 